Published in final edited form as:

Curr Opin Virol. 2015 April ; 11: 44-54. doi:10.1016/j.coviro.2014.12.009.

\title{
Viral Diseases of the Central Nervous System
}

\author{
Phillip A. Swanson II and Dorian B. McGavern \\ National Institute of Neurological Disorders and Stroke, National Institutes of Health, Bethesda, \\ MD 20892
}

\begin{abstract}
Virus-induced diseases of the central nervous system (CNS) represent a significant burden to human health worldwide. The complexity of these diseases is influenced by the sheer number of different neurotropic viruses, the diverse routes of CNS entry, viral tropism, and the immune system. Using a combination of human pathological data and experimental animal models, we have begun to uncover many of the mechanisms that viruses use to enter the CNS and cause disease. This review highlights a selection of neurotropic viruses that infect the CNS and explores the means by which they induce neurological diseases such as meningitis, encephalitis, and myelitis.
\end{abstract}

\section{INTRODUCTION}

The central nervous system (CNS) is protected by a highly complex barrier system, yet a wide variety of viruses still manage to gain access and induce disease. In fact, the number CNS viral infections each year is greater than all bacterial, fungal, and protozoa infections combined [1]. Following CNS infection, inflammation can arise in distinct anatomical regions such as the meninges (meningitis), brain (encephalitis), and spinal cord (myelitis), or simultaneously in multiple regions (meningoencephalitis, encephalomyelitis). For many neurotropic viruses, viral cytopathology plays a major role in CNS dysfunction. However, experimental animal models have revealed that the antiviral immune response can also under certain conditions be an active contributor to disease. This brief review will break down CNS viral pathogenesis into distinct anatomical regions and discuss selected viruses that drive pathology involved in each.

\section{CNS INVASION}

Although viruses breach protective barriers a number of different ways, there are basically two main routes of entry into the CNS (Figures 1, 2). One route of entry is via the blood supply. Viruses that are inhaled such as measles and mumps or ingested like human

\section{(C) 2015 Published by Elsevier B.V.}

Corresponding author: Dorian B. McGavern, Ph.D., NIH / NINDS, 10 Center Drive, Bethesda, MD 20892, Phone: (301) 443-7949, mcgavernd@mail.nih.gov.

Publisher's Disclaimer: This is a PDF file of an unedited manuscript that has been accepted for publication. As a service to our customers we are providing this early version of the manuscript. The manuscript will undergo copyediting, typesetting, and review of the resulting proof before it is published in its final citable form. Please note that during the production process errors may be discovered which could affect the content, and all legal disclaimers that apply to the journal pertain. 
enteroviruses are able to move quickly past mucosal epithelial barriers and establish infection in oropharyngeal or small bowel lymphoid tissues [2-4]. Arboviruses that enter the skin after an insect bite are picked up by Langerhans cells, which then migrate to the draining lymph node [5,6]. Once in secondary lymphoid tissues, viruses are often shed into the blood stream, resulting in systemic infection. The delicate CNS parenchyma is protected from harmful substances in the blood by an elaborate barrier network called the blood brain and blood cerebrospinal fluid barriers [7]. However, viruses have adapted one or more ways to overcome this obstacle [8]. Some viruses directly infect vascular endothelial cells, which allow direct passage across the blood brain barrier (BBB) into the CNS [9-11]. Additionally, there are areas of the CNS such as the choroid plexus and circumventricular organs that are not completely protected by the BBB and serve as entry points for several viruses $[12,13]$. Infected hematopoietic cells are also used as "Trojan horses" to transport virus into the CNS via the blood supply $[14,15]$. Finally, systemic viral infection can lead to inflammationinduced breakdown of the BBB [16,17], allowing viruses to literally slip through the cracks into the CNS.

As a second major route of CNS entry, some viruses infect and migrate through peripheral nerves. While rabies virus initially infects myocytes after a bite from an infected animal, and poliovirus infects mucosal epithelial cells after ingestion, they both use peripheral motor neurons to make their way into the CNS $[18,19]$. Herpes simplex virus (HSV)-1 initially infects keratinocytes before migrating to peripheral sensory neurons. HSV-1 has also been proposed to reach the CNS via olfactory sensory neurons whose dendrites are directly exposed to airways in the nose [20]. Nipah virus, influenza virus, and rabies virus have also been proposed to enter the CNS via olfactory nerves [21-24]. It is important to note, however, that while some viruses have a preference for the hematogenous or peripheral nerve route to CNS entry, other viruses are able to take advantage of both [25,26]. Once viruses reach the CNS, viral tropism and the ensuing immune response combine to shape the resulting disease. Viruses that remain within cells of the meninges or ventricular lining often induce meningitis, whereas those that infect the CNS parenchyma give rise to meningoencephalitis, encephalitis, or myelitis (Figures 1, 2). These virus-induced diseases will be discussed in more detail below.

\section{MENINGITIS}

Aseptic meningitis is classically defined as non-bacterial inflammation of the tissues lining the brain. Any inflammation or pathology that also involves the parenchyma is referred to as meningoencephalitis or encephalitis (discussed below). The vast majority of aseptic meningitis cases are caused by human enteroviruses (HEV) [27,28] that mostly target children $[29,30]$. However, many other viruses have the ability to cause meningitis including St. Louis encephalitis virus (SLEV) [31], bunyaviruses [32-34], mumps virus [35], lymphocytic choriomeningitis virus (LCMV) [36], HSV-1 and 2 [37,38], and human immunodeficiency virus (HIV)-1 [39]. Because most adult infections resolve without long term sequelae, pathological data are scarce. Common symptoms such as fever, headache, and neck stiffness are usually treated with supportive care, and these symptoms are driven in part by pleocytosis and elevated cytokines in the cerebrospinal fluid [40]. 
Animal models have helped elucidate some of the mechanisms that drive the pathogenesis of viral meningitis. Neonatal humans are especially at risk for developing severe morbidity and mortality following infection by group B coxsackieviruses and echoviruses [41,42]. A pathological report of a child who succumbed to coxsackievirus B5 noted intense inflammation around the choroid plexus as well as the lateral and fourth ventricles [43]. This is consistent with experimental data showing that the choroid plexus in coxsackievirus B3 (CVB3)-infected neonatal mice is heavily populated with virus-infected myeloid cells undergoing apoptosis [15]. Similarly, LCMV targets the choroid plexus and ependymal cells as well as stromal and innate immune cells in mice following intracerebral injection [44-46]. LCMV is likely transmitted from rodents to humans through ingestion of urine or fecalcontaminated food or exposure through an open wound. Most infections result in mild or no symptoms, and in rare cases of severe disease, immunocompetent individuals typically recover with supportive care $[47,48]$. However, LCMV infection can be fatal in immunocompromised individuals, such as solid-organ transplant recipients [49]. As an animal model of CNS disease, immunocompetent mice are infected intracerebrally with LCMV [50]. Following infection, mice uniformly develop fatal meningitis 6-7 days postinfection, which is characterized by heavy immune cell infiltration and vascular pathology within the meninges [51]. We have shown that this fatal disease is mediated in part by antiviral $\mathrm{CD}^{+} \mathrm{T}$ cells that directly release chemoattractants in the meninges, which promotes synchronous extravasation of innate myelomonocytic cells (i.e., monocytes and neutrophils) (Figure 3) [45]. As these innate cells extravasate through blood vessels, they open the tight junctions, contributing to dysregulation of CNS homeostasis and fatal edema [45]. Importantly, type I interferon (IFN-I) signaling is responsible for nearly all innate immune gene expression in the LCMV infected brain and sets the stage for the ensuing fatal immunopathology [52]. In fact, blockade of IFN-I signaling completely prevents LCMV meningitis and may therefore represent a therapeutic target to dampen pathogenic antiviral immune activity in the CNS [53,54].

\section{ENCEPHALITIS}

Viruses that infect neurons within the CNS can induce intense inflammation of the parenchyma (encephalitis) as well as the meninges (meningoencephalitis), leading to headache, fever, and neurological dysfunction (Figures 1, 2). HEVs and alphaviruses, such as Eastern, Western, and Venezuelan equine encephalitis viruses (EEEV, WEEV, VEEV) primarily infect neurons within the CNS, which has a cytopathic effect. HEVs are responsible for a large percentage of worldwide viral encephalitides [1]. Some examples include poliovirus (PV) outbreaks in Africa and Asia [55], EV71 in southeast Asia [56,57], and the recent EV68 outbreak in the United States [58]. EEEV, WEEV, and VEEV are insect transmitted viruses affecting different regions of the Americas, which can induce intense CNS disease mostly among young children and the elderly [59]. Post-mortem analysis of EV71-infected brains revealed virus-infected neurons, heavy immune cell infiltration, and destruction of nerve cells by phagocytes along the medulla, thalamus, hypothalamus, dentate nucleus, and cerebral cortex [56], consistent with experimental data [60]. The cytopathic effect of enteroviruses, which is likely one of the main drivers of inflammation and disease, has been linked to viral protein-induced apoptosis [61]. 
Alphavirus infection can similarly induce apoptosis within neurons [62]. Furthermore, alphaviruses can also indirectly cause neuronal death through the release of proinflammatory cytokines [63] and excitatory amino acids, which can lead to excessive activation of $N$-methyl-D-aspartate-subtype (NMDA) glutamate receptors [64]. Another possible factor contributing to the pathogenesis of human enteroviruses is how they migrate throughout the CNS. For example, CVB3, which can cause a devastating encephalitis in infants, targets neuronal stem cells in the subventricular zone of infected neonatal mice [65]. Over time, the infected stem cells continue to differentiate as they migrate along the rostral migratory stream, seeding the parenchyma with virus, before eventually succumbing to apoptosis. Many viruses are known to target neuronal stem cells because of their enhanced proliferative potential.

A second group of insect-transmitted encephalitic viruses (referred to as flaviviruses) can also target CNS neurons and cause cytopathology. However, unlike enteroviruses and alphaviruses, the immune response following infection of the CNS by flaviviruses seems to play a much larger role in disease pathogenesis. There are a range of disease susceptible hosts available to flaviviruses. Historically, Japanese encephalitis virus (JEV) is more likely to cause encephalitis in children, whereas the elderly are more susceptible to encephalitis following SLEV and West Nile virus (WNV) infection [66]. Pathological data from individuals who succumbed to WNV encephalitis revealed sparse but widely distributed lesions of neuronal cell death, gliosis, and innate immune cell infiltration found within the brain stem, cortex, hippocampus, and cerebellum [67]. Additionally, vasculitis and breakdown of the BBB was also observed following WNV infection [68]. Immune cell infiltration consisting of lymphocytes and macrophages in the brain stem, cerebellum and cortex is quite prominent following infection by tick-borne encephalitis virus (TBEV) and JEV [69,70]. Many focal areas of tissue necrosis can be found in JEV encephalitic brains, giving a "punched out" appearance.

At the cellular level, WNV antigen is primarily found within neurons and CD11 $\mathrm{b}^{+}$myeloid cells [71]. Infection of neurons induces apoptosis via a caspase3-dependent pathway [72]; however, necrosis due to excessive viral budding has also been observed [73]. Proinflammatory cytokines and reactive oxygen species (ROS) released from WNV-infected neurons [74] and activated microglia may also contribute to neurotoxicity [25,75]. JEV and TBEV trigger a similar detrimental innate immune reaction characterized by ROS production from macrophages [76,77]. In addition, in vivo treatment of infected mice with anti-inflammatory drugs confers protection [77,78]. Differences, however, among the flaviviruses have been noted regarding the role of the immune system in disease pathogenesis. For example, $\mathrm{CD} 8^{+} \mathrm{T}$ cells can contribute to pathogenesis during TBEV encephalitis [79], whereas lymphocytes have a protective role following WNV and JEV infections [80,81]. Thus, there are both positive and negative aspects of immune function to consider following flavivirus infection.

While many of the aforementioned viruses are directly neuropathic, viral encephalitis can also result from indirect mechanisms that disrupt neuronal function. This is best exemplified by HIV-1. Nearly $50 \%$ of HIV-1 infections lead to neurological complications that fall under the umbrella of HIV-associated neurocognitive disorders (HAND) [82]. HIV-1 
encephalitis (HIVE) underlies the most serious of these disorders called HIV-associated dementia (HAD), which is characterized by major cognitive and motor impairment [83]. HIV-1 enters the CNS within days of primary infection [84] via infected, circulating immune cells or as free virions. Infection and replication occurs primarily in perivascular macrophages and microglia [85] following genetic mutations that shift the virus towards a more macrophage-tropic phenotype with less reliance on the CD4 co-receptor for infection [86]. This compartmentalization of HIV-1 genetic variants is a major driver of HIVE [87]. The pathophysiology of HIVE is largely unknown, but there is evidence of neuronal death during this condition [88]. Because HIV-1 does not infect neurons, HAD is thought to occur due to the creation of a toxic environment for neurons rather than direct cytolysis. Many in vitro experiments have shown that exogenous addition of HIV-1 proteins (tat and gp120) have the ability to kill cultured neurons and promote release inflammatory cytokines [89-91]. However, it is currently debated whether the extracellular concentrations of these proteins would be high enough to achieve the same effect in vivo. In addition to viral proteins, activated macrophages and microglia could contribute to neuronal death via the release of inflammatory cytokines and free radicals or through the excessive activation of NMDA glutamate receptors [92], similar to alphaviruses.

Although the advent of antiretroviral therapy (ART) has greatly reduced the frequency of HAD, milder HAND disorders still persist [82]. This is likely due to a combination of longer life spans for HIV-infected individuals and a build-up of damage from continued low level inflammation. HIV-1 mRNA can still be detected in various brain regions of individuals on ART [93], possibly due to the fact that HIV-1 infects long lived CNS populations such as microglia and astrocytes [94]. Furthermore, pathology data from individuals on ART demonstrates widespread activation of CNS innate immune cells [95]. This chronic state of immune activation despite reduced viral loads likely disrupts CNS homeostasis and contributes to neurological dysfunction.

Another relevant inducer of disease in the CNS parenchyma is rabies virus. Encephalitic (furious) rabies accounts for nearly $80 \%$ of all CNS disease arising from rabies virus infection [19]. Interestingly, autopsies from patients who have succumbed to rabies encephalitis revealed very little immunopathology [96,97]. The disease is characterized by sporadic edema as well as mild perivascular infiltration, gliosis, and microglia nodules occurring mainly in the brainstem and thalamus. A number of factors have been proposed to contribute to this interesting phenotype, including active immune suppression [98-100] and neuronal dysfunction [101-103]. Apoptosis of neuronal cells has been proposed to contribute to pathogenesis [104,105]; however, these findings were based on infections using attenuated strains of virus, whereas wild type strains fail to induce neuronal apoptosis $[105,106]$.

CNS disease is also induced by viruses that establish latent or persistent infections. Over half of the adult population is infected by one such virus called John Cunningham virus (JCV) [107]. Most individuals are completely asymptomatic; however, during states of immunosuppression, JCV can cause progressive multifocal leukoencephalopathy (PML). This once rare disease characterized by infection of oligodendrocytes leading to multiple foci of demyelinated neurons in the brain has become more prevalent with the emergence of 
acquired immunodeficiency syndrome (AIDS) as well as various immunosuppressive treatments for autoimmune disorders. Currently, there are no animal models for PML, so our understanding of this disease comes entirely from human pathological data. Although the precise events that give rise to PML are not completely understood, the current hypothesis is that neurotropic $\mathrm{JCV}$ is reactivated from a peripheral latent reservoir following immunosuppression, particularly of CD4 T cells [108]. JCV then migrates to the CNS, possibly in B cells [109], where it crosses the BBB and infects oligodendrocytes. Before ART the prognosis for AIDS patients also suffering from PML was quite grim, but now with treatment $50 \%$ of patients survive greater than 12 months [110]. The prognosis is close to $80 \%$ survival for PML patients on immunosuppressive drugs such as natalizumab [111].

HSV-1, which establishes latency in trigeminal ganglia following primary infection, is responsible for over 90\% of the cases of HSV encephalitis (HSE) [112]. HSE most often affects the elderly as well as young children and can have a mortality rate, especially if left untreated [113,114]. However, it is still unknown whether HSE results from primary HSV-1 infection or reactivation of latent virus. Histological analysis of brain tissue from patients who succumbed to HSE revealed perivascular inflammatory infiltrates, HSV-infected neurons, and engulfment of neurons by microglia [115], typically in the frontal-temporal lobe [116]. Interestingly, there is also intense eosinophilia, although the role of eosinophils is unclear [115]. Despite these histological data, the mechanisms that drive HSE remain unknown. Some studies implicate a protective role for the immune system, as individuals with genetic deficiencies in IFN-I signaling [117] or those with immunosuppression are more susceptible to HSE [118]. However, others have shown that the innate immune response can be detrimental [119].

Measles virus $(\mathrm{MeV})$ can also establish a persistent infection in the CNS, which results in a disease called subacute sclerosing panencephalitis (SSPE). As many as 1:1700 children who contract measles before the age of 5 are at risk for SSPE [120]. The range of onset for SSPE is between 6-13 years [121], with early disease often going undiagnosed. Symptoms begin with cognitive defects, followed by seizures, neurological deterioration, and coma [4]. At the cellular level, neurons and glial cells are infected by $\mathrm{MeV}$, and there is a large infiltration of both innate immune cells and lymphocytes [122,123]; however, this response is unable to clear virus. Several hypotheses have been put forth to explain the mechanism(s) of viral persistence. Viral transmission can occur via cell-cell fusion between infected and uninfected neurons [124], which would effectively thwart the neutralizing antibody response. Alternatively, the antibody response might also contribute to $\mathrm{MeV}$ persistence by altering the primary immune response or modulating CNS immunity [4]. Evidence for this theory comes from experiments showing that passive transfer of $\mathrm{MeV}$-specific antibodies rescues infected rats from acute disease, but leads to persistent viral infection and chronic encephalitis [125].

\section{MYELITIS}

Some neurotropic viruses primarily impact brain tissue, whereas others cause disease in the spinal cord (Figure 2). A prototypic example of the latter is poliomyelitis. Poliomyelitis derives from the ancient Greek words for "gray" (referring to the gray matter of the spinal 
cord) and "inflammation". In the strictest definition of the term, it refers to inflammation of the spinal cord caused by poliovirus. However, this term is frequently used to phenotypically describe other cases of virus-induced myelitis with similar pathology, such as WNV and EV71. Poliovirus, EV71, WNV, TBEV, and JEV infections have all been associated with acute flaccid paralysis. In each case, viral antigen was found in neuronal cells bodies residing in the anterior horn of the spinal cord (Figure 2), often coupled with intense perivascular inflammation [56,126-130]. Experiments using hamsters have shown that WNV migration to the spinal cord via peripheral neurons [131] and subsequent injury to anterior horn neurons is responsible for limb paralysis [132]. Although virus-induced cytopathology is undoubtedly contributing to the destruction of motor neurons, the role of immunemediated pathology in this disease remains unknown.

Rabies virus can also cause disease in the spinal cord. Paralytic (dumb) rabies is much less common that furious rabies [19]. Nevertheless, one pathological study noted that symptoms associated with paralytic rabies began with pain in bite area, followed by motor weakness in the affected limb, and progressed to rapid onset motor paralysis in other limbs [133]. Similar to poliomyelitis, this was associated with heavy inflammation in the anterior horns of the spinal cord, which was associated with motor neuron loss. Dorsal root ganglion neurons are also infected. Rabies virus can eventually give rise to segmental demyelination in peripheral and spinal cord nerves, and electrophysiological experiments have implicated peripheral nerve demyelination as the cause for rabies paralysis [134].

\section{CONCLUSION}

Great strides have been made to identify viruses that infect the CNS and mechanisms they use to cause disease. However, many viruses that drive CNS disease remain unidentified and thus it is imperative to survey cohorts of patients with neurological diseases suspected to have an infectious etiology [135]. While human pathology studies have been instrumental in identifying CNS regions affected by neurotropic viruses, the development of experimental animal models are often critical for the discovery of immunological and virological mechanisms that lead to CNS diseases. For example, in vitro and in vivo models have helped uncover the role of apoptosis and specific viral proteins in the pathogenesis of enterovirus, alphavirus, and flavirus infection of neurons. Animal models have also shed light on the immunological mechanisms that contribute to tissue damage and neurological dysfunction following CNS infection. The immune system is initially mobilized to defend the CNS from a viral invader, but can sometimes participate in devastating pathological reactions. Despite the diversity of viruses that invade the CNS, many infections induce common pathogenic cascades such as break down of CNS barriers and release of potentially detrimental mediators (e.g. TNF- $a$, IFN-I, ROS, and glutamate) that can cause neurotoxicity. These universal mediators could serve as therapeutic targets to lessen the pathogenesis associated with many different CNS viral infections. The IFN-I pathway, for example, plays an important role in the CNS defense against most viral infections [136], and modulation of this pathway might provide a therapeutic means to control the magnitude of CNS inflammatory responses. Many advances in our understanding of neurotropic viruses have been made thus far, but more research is required to improve our ability to rapidly diagnose and then treat CNS infections [137], especially for viruses like JCV that have no animal model. Viral 
diseases of the CNS represent a significant burden to the global community, and the only way to lessen this burden is through a concerted research effort that involves pathogen discovery, animal model and therapeutic development, and intervention studies.

\section{ACKNOWLEDGMENTS}

This work was supported by National Institutes of Health (NIH) intramural program. P.S. is presently supported by a NIH Intramural Competitive Fellowship. We would like to thank Ethan Tyler and Alan Hoofring in the NIH Medical Arts Design Section for their help with the illustrations.

\section{REFERENCES}

1. Romero JR, Newland JG. Viral meningitis and encephalitis: traditional and emerging viral agents. Semin Pediatr Infect Dis. 2003; 14:72-82. [PubMed: 12881794]

2. Tyor W, Harrison T. Mumps and rubella. Handb Clin Neurol. 2014; 123:591-600. [PubMed: 25015506]

3. Jubelt B, Lipton HL. Enterovirus/picornavirus infections. Handb Clin Neurol. 2014; 123:379-416. [PubMed: 25015496]

4. Griffin DE. Measles virus and the nervous system. Handb Clin Neurol. 2014; 123:577-590. [PubMed: 25015505]

*5. Wu SJ, Grouard-Vogel G, Sun W, Mascola JR, Brachtel E, Putvatana R, Louder MK, Filgueira L, Marovich MA, Wong HK, et al. Human skin Langerhans cells are targets of dengue virus infection. Nat Med. 2000; 6:816-820. This study showed that skin dendritic cells are permissive to dengue virus infection and serve as a portal of entry to the body. [PubMed: 10888933]

6. Byrne SN, Halliday GM, Johnston LJ, King NJ. Interleukin-1beta but not tumor necrosis factor is involved in West Nile virus-induced Langerhans cell migration from the skin in C57BL/6 mice. $\mathrm{J}$ Invest Dermatol. 2001; 117:702-709. [PubMed: 11564180]

**7. Ransohoff RM, Kivisakk P, Kidd G. Three or more routes for leukocyte migration into the central nervous system. Nat Rev Immunol. 2003; 3:569-581. This excellent review details the anatomical structures of the blood brain and blood cerebral spinal fluid barriers. [PubMed: 12876559]

*8. McGavern DB, Kang SS. Illuminating viral infections in the nervous system. Nat Rev Immunol. $2011 ; 11: 318-329$. This review describes strategies used by viruses to enter the CNS and how the immune system responds to persistent / latent viral infections. [PubMed: 21508982]

9. Verma S, Lo Y, Chapagain M, Lum S, Kumar M, Gurjav U, Luo H, Nakatsuka A, Nerurkar VR. West Nile virus infection modulates human brain microvascular endothelial cells tight junction proteins and cell adhesion molecules: Transmigration across the in vitro blood-brain barrier. Virology. 2009; 385:425-433. [PubMed: 19135695]

10. Moses AV, Bloom FE, Pauza CD, Nelson JA. Human immunodeficiency virus infection of human brain capillary endothelial cells occurs via a CD4/galactosylceramide-independent mechanism. Proc Natl Acad Sci U S A. 1993; 90:10474-10478. [PubMed: 7504264]

11. Coyne CB, Kim KS, Bergelson JM. Poliovirus entry into human brain microvascular cells requires receptor-induced activation of SHP-2. EMBO J. 2007; 26:4016-4028. [PubMed: 17717529]

12. van Den Pol AN, Mocarski E, Saederup N, Vieira J, Meier TJ. Cytomegalovirus cell tropism, replication, and gene transfer in brain. J Neurosci. 1999; 19:10948-10965. [PubMed: 10594076]

13. Wolinsky JS, Baringer JR, Margolis G, Kilham L. Ultrastructure of mumps virus replication in newborn hamster central nervous system. Lab Invest. 1974; 31:403-412. [PubMed: 4607324]

*14. Clay CC, Rodrigues DS, Ho YS, Fallert BA, Janatpour K, Reinhart TA, Esser U. Neuroinvasion of fluorescein-positive monocytes in acute simian immunodeficiency virus infection. J Virol. 2007; 81:12040-12048. This study used fluorescently labeled PBMCs to demonstrate that monocyte trafficking into the CNS of SIV-infected primates coincides with viral neuroinvasion. [PubMed: 17715237]

15. Tabor-Godwin JM, Ruller CM, Bagalso N, An N, Pagarigan RR, Harkins S, Gilbert PE, Kiosses WB, Gude NA, Cornell CT, et al. A novel population of myeloid cells responding to 
coxsackievirus infection assists in the dissemination of virus within the neonatal CNS. J Neurosci. 2010; 30:8676-8691. [PubMed: 20573913]

16. Arsenio-Nunes ML, Cerutti I, Farkas-Bargeton E. Vascular and neuroglial changes in experimental herpes simplex encephalitis: ultrastructural study. Acta Neuropathol (Berl). 1975; 33:245-256. [PubMed: 174381]

17. Eugenin EA, Osiecki K, Lopez L, Goldstein H, Calderon TM, Berman JW. CCL2/monocyte chemoattractant protein-1 mediates enhanced transmigration of human immunodeficiency virus (HIV)-infected leukocytes across the blood-brain barrier: a potential mechanism of HIV-CNS invasion and NeuroAIDS. J Neurosci. 2006; 26:1098-1106. [PubMed: 16436595]

18. Racaniello VR. One hundred years of poliovirus pathogenesis. Virology. 2006; 344:9-16. [PubMed: 16364730]

19. Jackson AC. Rabies. Handb Clin Neurol. 2014; 123:601-618. [PubMed: 25015507]

20. Mori I, Nishiyama Y, Yokochi T, Kimura Y. Olfactory transmission of neurotropic viruses. J Neurovirol. 2005; 11:129-137. [PubMed: 16036791]

*21. Munster VJ, Prescott JB, Bushmaker T, Long D, Rosenke R, Thomas T, Scott D, Fischer ER, Feldmann H, de Wit E. Rapid Nipah virus entry into the central nervous system of hamsters via the olfactory route. Sci Rep. 2012:2-736. This immunochemical study provided the first data showing that Nipah virus enters the CNS via olfactory nerves in the nose.

22. Schrauwen EJ, Herfst S, Leijten LM, van Run P, Bestebroer TM, Linster M, Bodewes R, Kreijtz JH, Rimmelzwaan GF, Osterhaus AD, et al. The multibasic cleavage site in H5N1 virus is critical for systemic spread along the olfactory and hematogenous routes in ferrets. J Virol. 2012; 86:3975-3984. [PubMed: 22278228]

23. Constantine DG. Rabies transmission by nonbite route. Public Health Rep. 1962; 77:287-289. [PubMed: 13880956]

24. Winkler WG, Fashinell TR, Leffingwell L, Howard P, Conomy P. Airborne rabies transmission in a laboratory worker. JAMA. 1973; 226:1219-1221. [PubMed: 4800498]

25. Cho H, Diamond MS. Immune responses to West Nile virus infection in the central nervous system. Viruses. 2012; 4:3812-3830. [PubMed: 23247502]

26. Nathanson N. The pathogenesis of poliomyelitis: what we don't know. Adv Virus Res. 2008; 71:150. [PubMed: 18585526]

27. Rotbart HA. Viral meningitis. Semin Neurol. 2000; 20:277-292. [PubMed: 11051293]

28. Johnson RT, Buescher EL, Rogers NG, Funken-Busch MJ, Oliu WE. Epidemic central nervous system disease of mixed enterovirus etiology. II. Analysis of laboratory investigations. Am J Hyg. 1960; 71:331-341. [PubMed: 14407515]

29. Nonpolio enterovirus and human parechovirus surveillance --- United States, 2006-2008. MMWR Morb Mortal Wkly Rep. 2010; 59:1577-1580. [PubMed: 21150865]

30. Michos AG, Syriopoulou VP, Hadjichristodoulou C, Daikos GL, Lagona E, Douridas P, Mostrou G, Theodoridou M. Aseptic meningitis in children: analysis of 506 cases. PLoS ONE. 2007; 2:e674. [PubMed: 17668054]

31. Tsai TF, Canfield MA, Reed CM, Flannery VL, Sullivan KH, Reeve GR, Bailey RE, Poland JD. Epidemiological aspects of a St. Louis encephalitis outbreak in Harris County, Texas, 1986. J Infect Dis. 1988; 157:351-356. [PubMed: 2891777]

32. Balfour HH Jr. Siem RA, Bauer H, Quie PG. California arbovirus (La Crosse) infections. I. Clinical and laboratory findings in 66 children with meningoencephalitis. Pediatrics. 1973; 52:680-691. [PubMed: 4355363]

33. Srihongse S, Grayson MA, Deibel R. California serogroup viruses in New York State: the role of subtypes in human infections. Am J Trop Med Hyg. 1984; 33:1218-1227. [PubMed: 6507732]

34. Goodpasture HC, Poland JD, Francy DB, Bowen GS, Horn KA. Colorado tick fever: clinical, epidemiologic, and laboratory aspects of 228 cases in Colorado in 1973-1974. Ann Intern Med. 1978; 88:303-310. [PubMed: 204240]

35. Bang HO, Bang J. Involvement of the Central Nervous System in Mumps. Acta Med Scand. 1943; 113:487-505.

36. Skogland JE, Baker AB. An unusual form of lymphocytic choriomeningitis. Arch Neuro Psychiatr. $1939 ; 42: 507-512$. 
37. Olson LC, Buescher EL, Artenstein MS, Parkman PD. Herpesvirus infections of the human central nervous system. N Engl J Med. 1967; 277:1271-1277. [PubMed: 4294512]

38. Rathore MH, Mercurio K, Halstead D. Herpes simplex virus type 1 meningitis. Pediatr Infect Dis J. 1996; 15:824-828. [PubMed: 8878229]

39. Hollander H, Stringari S. Human immunodeficiency virus-associated meningitis. Clinical course and correlations. Am J Med. 1987; 83:813-816. [PubMed: 3674088]

40. Liu S, Lee P, Lee C, Wang J, Chiang B, Chou M. Different Cytokine Levels in Enterovirus Meningitis and Encephalitis. Infect Dis Clin Prac. 2005; 13:241-246.

41. Dalwai A, Ahmad S, Al-Nakib W. Echoviruses are a major cause of aseptic meningitis in infants and young children in Kuwait. Virol J. 2010; 7:236. [PubMed: 20846386]

42. Romero JR. Pediatric group B coxsackievirus infections. Curr Top Microbiol Immunol. 2008; 323:223-239. [PubMed: 18357772]

43. Price RA, Garcia JH, Rightsel WA. Choriomeningitis and myocarditis in an adolescent with isolation of coxsackie B-5 virus. Am J Clin Pathol. 1970; 53:825-831. [PubMed: 5504603]

44. Schwendemann G, Lohler J, Lehmann-Grube F. Evidence for cytotoxic T-lymphocyte-target cell interaction in brains of mice infected intracerebrally with lymphocytic choriomeningitis virus. Acta Neuropathol (Berl). 1983; 61:183-195. [PubMed: 6606284]

**45. Kim JV, Kang SS, Dustin ML, McGavern DB. Myelomonocytic cell recruitment causes fatal CNS vascular injury during acute viral meningitis. Nature. 2009; 457:191-195. This intravital imaging study provided the first data showing that cytotoxic lymphocytes can promote synchronous extravasaton of myelomonocytic cells that damage meningeal blood vessels, contributing to fatal edema during LCMV meningitis. [PubMed: 19011611]

**46. Kang SS, Herz J, Kim JV, Nayak D, Stewart-Hutchinson P, Dustin ML, McGavern DB. Migration of cytotoxic lymphocytes in cell cycle permits local MHC I-dependent control of division at sites of viral infection. J Exp Med. 2011; 208:747-759. This study provided the first data showing that antiviral cytotoxic lymphocytes can migrate through the blood in active stages of cell cycle and undergo cytokinesis upon arrival in the virally infected meninges. [PubMed: 21464219]

47. Roebroek RM, Postma BH, Dijkstra UJ. Aseptic meningitis caused by the lymphocytic choriomeningitis virus. Clin Neurol Neurosurg. 1994; 96:178-180. [PubMed: 7924087]

48. Asnis DS, Muana O, Kim do G, Garcia M, Rollin PE, Slavinski S. Lymphocytic choriomeningitis virus meningitis, New York, NY, USA, 2009. Emerg Infect Dis. 2010; 16:328-330. [PubMed: 20113573]

49. Lymphocytic choriomeningitis virus infection in organ transplant recipients--Massachusetts, Rhode Island, 2005. MMWR Morb Mortal Wkly Rep. 2005; 54:537-539. [PubMed: 15931158]

50. Kang SS, McGavern DB. Lymphocytic choriomeningitis infection of the central nervous system. Front Biosci. 2008; 13:4529-4543. [PubMed: 18508527]

**51. McGavern DB, Christen U, Oldstone MB. Molecular anatomy of antigen-specific CD8(+) T cell engagement and synapse formation in vivo. Nat Immunol. 2002; 3:918-925. This study demonstrated that antiviral cytotoxic lymphocytes form immunological synapses with infected targets in the virally infected meninges and can engage up to three targets simultaneously to improve killing efficiency. [PubMed: 12352968]

*52. Nayak D, Johnson KR, Heydari S, Roth TL, Zinselmeyer BH, McGavern DB. Type I interferon programs innate myeloid dynamics and gene expression in the virally infected nervous system. PLoS Pathog. 2013; 9:e1003395. Type I interferon was determined in this paper to be responsible for all innate immune gene expression and immune cell dynamics in the brain following infection with LCMV. [PubMed: 23737750]

**53. Muller U, Steinhoff U, Reis LF, Hemmi S, Pavlovic J, Zinkernagel RM, Aguet M. Functional role of type I and type II interferons in antiviral defense. Science. 1994; 264:1918-1921. This study used genetic knockout mice to demonstrate that type I and type II interferons are both required for antiviral immunity. [PubMed: 8009221]

54. Sandberg K, Kemper P, Stalder A, Zhang J, Hobbs MV, Whitton JL, Campbell IL. Altered tissue distribution of viral replication and $\mathrm{T}$ cell spreading is pivotal in the protection against fatal 
lymphocytic choriomeningitis in mice after neutralization of IFN-alpha/beta. J Immunol. 1994; 153:220-231. [PubMed: 8207238]

55. Aylward B, Yamada T. The polio endgame. N Engl J Med. 2011; 364:2273-2275. [PubMed: 21675884]

56. Wong KT, Munisamy B, Ong KC, Kojima H, Noriyo N, Chua KB, Ong BB, Nagashima K. The distribution of inflammation and virus in human enterovirus 71 encephalomyelitis suggests possible viral spread by neural pathways. J Neuropathol Exp Neurol. 2008; 67:162-169. [PubMed: 18219253]

57. Huang CC, Liu CC, Chang YC, Chen CY, Wang ST, Yeh TF. Neurologic complications in children with enterovirus 71 infection. N Engl J Med. 1999; 341:936-942. [PubMed: 10498488]

58. Pastula DM, Aliabadi N, Haynes AK, Messacar K, Schreiner T, Maloney J, Dominguez SR, Davizon ES, Leshem E, Fischer M, et al. Acute neurologic illness of unknown etiology in children - colorado, august-september 2014. MMWR Morb Mortal Wkly Rep. 2014; 63:901-902. [PubMed: 25299607]

59. Greenlee JE. The equine encephalitides. Handb Clin Neurol. 2014; 123:417-432. [PubMed: 25015497]

60. Nagata N, Iwasaki T, Ami Y, Tano Y, Harashima A, Suzaki Y, Sato Y, Hasegawa H, Sata T, Miyamura T, et al. Differential localization of neurons susceptible to enterovirus 71 and poliovirus type 1 in the central nervous system of cynomolgus monkeys after intravenous inoculation. J Gen Virol. 2004; 85:2981-2989. [PubMed: 15448361]

61. Kuo RL, Kung SH, Hsu YY, Liu WT. Infection with enterovirus 71 or expression of its $2 \mathrm{~A}$ protease induces apoptotic cell death. J Gen Virol. 2002; 83:1367-1376. [PubMed: 12029152]

62. Jan JT, Griffin DE. Induction of apoptosis by Sindbis virus occurs at cell entry and does not require virus replication. J Virol. 1999; 73:10296-10302. [PubMed: 10559347]

63. Schoneboom BA, Catlin KM, Marty AM, Grieder FB. Inflammation is a component of neurodegeneration in response to Venezuelan equine encephalitis virus infection in mice. $\mathrm{J}$ Neuroimmunol. 2000; 109:132-146. [PubMed: 10996215]

*64. Nargi-Aizenman JL, Griffin DE. Sindbis virus-induced neuronal death is both necrotic and apoptotic and is ameliorated by N-methyl-D-aspartate receptor antagonists. J Virol. 2001; 75:7114-7121. Using NMDA receptor antagonists, the authors of this study demonstrated that virus-induced death of cortical neurons is mediated by glutamate excitotoxicity. [PubMed: 11435592]

**65. Feuer R, Pagarigan RR, Harkins S, Liu F, Hunziker IP, Whitton JL. Coxsackievirus targets proliferating neuronal progenitor cells in the neonatal CNS. J Neurosci. 2005; 25:2434-2444. This study demonstrated how coxsackievirus B3 seeds the neonatal brain by infecting neuroprogenitor cells, which then migrate along the rostral migratory stream. [PubMed: 15745971]

66. Chambers TJ, Diamond MS. Pathogenesis of flavivirus encephalitis. Adv Virus Res. 2003; 60:273-342. [PubMed: 14689697]

67. Omalu BI, Shakir AA, Wang G, Lipkin WI, Wiley CA. Fatal fulminant pan-meningopolioencephalitis due to West Nile virus. Brain Pathol. 2003; 13:465-472. [PubMed: 14655752]

**68. Wang T, Town T, Alexopoulou L, Anderson JF, Fikrig E, Flavell RA. Toll-like receptor 3 mediates West Nile virus entry into the brain causing lethal encephalitis. Nat Med. 2004; 10:1366-1373. The authors demonstrated that fatal encephalitis following peripheral infection by WNV is dependent upon TLR3 signaling which leads to TNF-a mediated breakdown of the blood brain barrier and viral dissemination throughout the CNS. [PubMed: 15558055]

69. German AC, Myint KS, Mai NT, Pomeroy I, Phu NH, Tzartos J, Winter P, Collett J, Farrar J, Barrett A, et al. A preliminary neuropathological study of Japanese encephalitis in humans and a mouse model. Trans R Soc Trop Med Hyg. 2006; 100:1135-1145. [PubMed: 16814333]

70. Lindquist L. Tick-borne encephalitis. Handb Clin Neurol. 2014; 123:531-559. [PubMed: 25015503]

71. Daffis S, Samuel MA, Suthar MS, Gale M Jr. Diamond MS. Toll-like receptor 3 has a protective role against West Nile virus infection. J Virol. 2008; 82:10349-10358. [PubMed: 18715906] 
72. Samuel MA, Morrey JD, Diamond MS. Caspase 3-dependent cell death of neurons contributes to the pathogenesis of West Nile virus encephalitis. J Virol. 2007; 81:2614-2623. [PubMed: 17192305]

73. Chu JJ, Ng ML. The mechanism of cell death during West Nile virus infection is dependent on initial infectious dose. J Gen Virol. 2003; 84:3305-3314. [PubMed: 14645911]

74. Kumar M, Verma S, Nerurkar VR. Pro-inflammatory cytokines derived from West Nile virus (WNV)-infected SK-N-SH cells mediate neuroinflammatory markers and neuronal death. J Neuroinflammation. 2010; 7:73. [PubMed: 21034511]

75. Chao CC, Hu S, Ehrlich L, Peterson PK. Interleukin-1 and tumor necrosis factor-alpha synergistically mediate neurotoxicity: involvement of nitric oxide and of N-methyl-D-aspartate receptors. Brain Behav Immun. 1995; 9:355-365. [PubMed: 8903852]

76. Nazmi A, Dutta K, Das S, Basu A. Japanese encephalitis virus-infected macrophages induce neuronal death. J Neuroimmune Pharmacol. 2011; 6:420-433. [PubMed: 21424747]

77. Kreil TR, Eibl MM. Nitric oxide and viral infection: NO antiviral activity against a flavivirus in vitro, and evidence for contribution to pathogenesis in experimental infection in vivo. Virology. 1996; 219:304-306. [PubMed: 8623546]

78. Mishra MK, Basu A. Minocycline neuroprotects, reduces microglial activation, inhibits caspase 3 induction, and viral replication following Japanese encephalitis. J Neurochem. 2008; 105:15821595. [PubMed: 18208541]

79. Ruzek D, Salat J, Palus M, Gritsun TS, Gould EA, Dykova I, Skallova A, Jelinek J, Kopecky J, Grubhoffer L. CD8+ T-cells mediate immunopathology in tick-borne encephalitis. Virology. 2009; 384:1-6. [PubMed: 19070884]

80. Larena M, Regner M, Lee E, Lobigs M. Pivotal role of antibody and subsidiary contribution of CD8+ T cells to recovery from infection in a murine model of Japanese encephalitis. J Virol. 2011; 85:5446-5455. [PubMed: 21450826]

81. Iwamoto M, Jernigan DB, Guasch A, Trepka MJ, Blackmore CG, Hellinger WC, Pham SM, Zaki S, Lanciotti RS, Lance-Parker SE, et al. Transmission of West Nile virus from an organ donor to four transplant recipients. N Engl J Med. 2003; 348:2196-2203. [PubMed: 12773646]

82. Heaton RK, Clifford DB, Franklin DR Jr. Woods SP, Ake C, Vaida F, Ellis RJ, Letendre SL, Marcotte TD, Atkinson JH, et al. HIV-associated neurocognitive disorders persist in the era of potent antiretroviral therapy: CHARTER Study. Neurology. 2010; 75:2087-2096. [PubMed: 21135382]

83. Grill MF, Price RW. Central nervous system HIV-1 infection. Handb Clin Neurol. 2014; 123:487505. [PubMed: 25015501]

84. Davis LE, Hjelle BL, Miller VE, Palmer DL, Llewellyn AL, Merlin TL, Young SA, Mills RG, Wachsman W, Wiley CA. Early viral brain invasion in iatrogenic human immunodeficiency virus infection. Neurology. 1992; 42:1736-1739. [PubMed: 1513462]

85. Burdo TH, Lackner A, Williams KC. Monocyte/macrophages and their role in HIV neuropathogenesis. Immunol Rev. 2013; 254:102-113. [PubMed: 23772617]

86. Thomas ER, Dunfee RL, Stanton J, Bogdan D, Taylor J, Kunstman K, Bell JE, Wolinsky SM, Gabuzda D. Macrophage entry mediated by HIV Envs from brain and lymphoid tissues is determined by the capacity to use low CD4 levels and overall efficiency of fusion. Virology. 2007; 360:105-119. [PubMed: 17084877]

*87. Brown RJ, Peters PJ, Caron C, Gonzalez-Perez MP, Stones L, Ankghuambom C, Pondei K, McClure CP, Alemnji G, Taylor S, et al. Intercompartmental recombination of HIV-1 contributes to env intrahost diversity and modulates viral tropism and sensitivity to entry inhibitors. J Virol. 2011; 85:6024-6037. Genetic analyses of HIV-1 from different tissues revealed that intercompartmental recombination leads to viral diversity and phenotypic changes within a single host. [PubMed: 21471230]

88. Everall IP, Luthert PJ, Lantos PL. Neuronal loss in the frontal cortex in HIV infection. Lancet. 1991; 337:1119-1121. [PubMed: 1674013]

89. Bagashev A, Sawaya BE. Roles and functions of HIV-1 Tat protein in the CNS: an overview. Virol J. 2013; 10:358. [PubMed: 24359561] 
**90. Dreyer EB, Kaiser PK, Offermann JT, Lipton SA. HIV-1 coat protein neurotoxicity prevented by calcium channel antagonists. Science. 1990; 248:364-367. This study demonstrated that HIV-1 gp120 protein induces neurotoxicity by increasing intracellular calcium levels. [PubMed: 2326646]

91. Kaul M, Lipton SA. Chemokines and activated macrophages in HIV gp120-induced neuronal apoptosis. Proc Natl Acad Sci U S A. 1999; 96:8212-8216. [PubMed: 10393974]

92. Kaul M, Garden GA, Lipton SA. Pathways to neuronal injury and apoptosis in HIV-associated dementia. Nature. 2001; 410:988-994. [PubMed: 11309629]

93. Kumar AM, Borodowsky I, Fernandez B, Gonzalez L, Kumar M. Human immunodeficiency virus type 1 RNA Levels in different regions of human brain: quantification using real-time reverse transcriptase-polymerase chain reaction. J Neurovirol. 2007; 13:210-224. [PubMed: 17613711]

94. Gorry PR, Ong C, Thorpe J, Bannwarth S, Thompson KA, Gatignol A, Vesselingh SL, Purcell DF. Astrocyte infection by HIV-1: mechanisms of restricted virus replication, and role in the pathogenesis of HIV-1-associated dementia. Curr HIV Res. 2003; 1:463-473. [PubMed: 15049431]

95. Anthony IC, Ramage SN, Carnie FW, Simmonds P, Bell JE. Influence of HAART on HIV-related CNS disease and neuroinflammation. J Neuropathol Exp Neurol. 2005; 64:529-536. [PubMed: 15977645]

96. Nuovo GJ, Defaria DL, Chanona-Vilchi JG, Zhang Y. Molecular detection of rabies encephalitis and correlation with cytokine expression. Mod Pathol. 2005; 18:62-67. [PubMed: 15389258]

97. Murphy FA. Rabies pathogenesis. Arch Virol. 1977; 54:279-297. [PubMed: 907476]

98. Vidy A, Chelbi-Alix M, Blondel D. Rabies virus P protein interacts with STAT1 and inhibits interferon signal transduction pathways. J Virol. 2005; 79:14411-14420. [PubMed: 16254375]

99. Wiktor TJ, Doherty PC, Koprowski H. Suppression of cell-mediated immunity by street rabies virus. J Exp Med. 1977; 145:1617-1622. [PubMed: 301176]

100. Brzozka K, Finke S, Conzelmann KK. Identification of the rabies virus alpha/beta interferon antagonist: phosphoprotein P interferes with phosphorylation of interferon regulatory factor 3 . J Virol. 2005; 79:7673-7681. [PubMed: 15919920]

101. Fu ZF, Weihe E, Zheng YM, Schafer MK, Sheng H, Corisdeo S, Rauscher FJ 3rd, Koprowski H, Dietzschold B. Differential effects of rabies and borna disease viruses on immediate-early- and late-response gene expression in brain tissues. J Virol. 1993; 67:6674-6681. [PubMed: 8411369]

102. Tsiang H. Neuronal function impairment in rabies-infected rat brain. J Gen Virol. 1982; 61:277281. Pt 2. [PubMed: 7119753]

103. Ceccaldi PE, Fillion MP, Ermine A, Tsiang H, Fillion G. Rabies virus selectively alters 5-HT1 receptor subtypes in rat brain. Eur J Pharmacol. 1993; 245:129-138. [PubMed: 8491253]

104. Jackson AC, Rossiter JP. Apoptosis plays an important role in experimental rabies virus infection. J Virol. 1997; 71:5603-5607. [PubMed: 9188634]

105. Morimoto K, Hooper DC, Spitsin S, Koprowski H, Dietzschold B. Pathogenicity of different rabies virus variants inversely correlates with apoptosis and rabies virus glycoprotein expression in infected primary neuron cultures. J Virol. 1999; 73:510-518. [PubMed: 9847357]

106. Yan X, Prosniak M, Curtis MT, Weiss ML, Faber M, Dietzschold B, Fu ZF. Silver-haired bat rabies virus variant does not induce apoptosis in the brain of experimentally infected mice. $\mathrm{J}$ Neurovirol. 2001; 7:518-527. [PubMed: 11704884]

107. Berger JR. Progressive multifocal leukoencephalopathy. Handb Clin Neurol. 2014; 123:357-376. [PubMed: 25015495]

108. Weber F, Goldmann C, Kramer M, Kaup FJ, Pickhardt M, Young P, Petry H, Weber T, Luke W. Cellular and humoral immune response in progressive multifocal leukoencephalopathy. Ann Neurol. 2001; 49:636-642. [PubMed: 11357954]

109. Houff SA, Major EO, Katz DA, Kufta CV, Sever JL, Pittaluga S, Roberts JR, Gitt J, Saini N, Lux $\mathrm{W}$. Involvement of JC virus-infected mononuclear cells from the bone marrow and spleen in the pathogenesis of progressive multifocal leukoencephalopathy. N Engl J Med. 1988; 318:301-305. [PubMed: 2827029]

110. Antinori A, Ammassari A, Giancola ML, Cingolani A, Grisetti S, Murri R, Alba L, Ciancio B, Soldani F, Larussa D, et al. Epidemiology and prognosis of AIDS-associated progressive 
multifocal leukoencephalopathy in the HAART era. J Neurovirol. 2001; 7:323-328. [PubMed: 11517411]

111. Clifford DB, De Luca A, Simpson DM, Arendt G, Giovannoni G, Nath A. Natalizumabassociated progressive multifocal leukoencephalopathy in patients with multiple sclerosis: lessons from 28 cases. Lancet Neurol. 2010; 9:438-446. [PubMed: 20298967]

112. Aurelius E, Johansson B, Skoldenberg B, Forsgren M. Encephalitis in immunocompetent patients due to herpes simplex virus type 1 or 2 as determined by type-specific polymerase chain reaction and antibody assays of cerebrospinal fluid. J Med Virol. 1993; 39:179-186. [PubMed: 8385702]

113. Granerod J, Ambrose HE, Davies NW, Clewley JP, Walsh AL, Morgan D, Cunningham R, Zuckerman M, Mutton KJ, Solomon T, et al. Causes of encephalitis and differences in their clinical presentations in England: a multicentre, population-based prospective study. Lancet Infect Dis. 2010; 10:835-844. [PubMed: 20952256]

114. Skoldenberg B, Forsgren M, Alestig K, Bergstrom T, Burman L, Dahlqvist E, Forkman A, Fryden A, Lovgren K, Norlin K, et al. Acyclovir versus vidarabine in herpes simplex encephalitis. Randomised multicentre study in consecutive Swedish patients. Lancet. 1984; 2:707-711. [PubMed: 6148470]

115. Hatanpaa KJ, Kim JH. Neuropathology of viral infections. Handb Clin Neurol. 2014; 123:193214. [PubMed: 25015486]

116. Kleinschmidt-DeMasters BK, Gilden DH. The expanding spectrum of herpesvirus infections of the nervous system. Brain Pathol. 2001; 11:440-451. [PubMed: 11556690]

117. Dupuis S, Jouanguy E, Al-Hajjar S, Fieschi C, Al-Mohsen IZ, Al-Jumaah S, Yang K, Chapgier A, Eidenschenk C, Eid P, et al. Impaired response to interferon-alpha/beta and lethal viral disease in human STAT1 deficiency. Nat Genet. 2003; 33:388-391. [PubMed: 12590259]

118. Bradford RD, Pettit AC, Wright PW, Mulligan MJ, Moreland LW, McLain DA, Gnann JW, Bloch KC. Herpes simplex encephalitis during treatment with tumor necrosis factor-alpha inhibitors. Clin Infect Dis. 2009; 49:924-927. [PubMed: 19681709]

119. Lundberg P, Ramakrishna C, Brown J, Tyszka JM, Hamamura M, Hinton DR, Kovats S, Nalcioglu O, Weinberg K, Openshaw H, et al. The immune response to herpes simplex virus type 1 infection in susceptible mice is a major cause of central nervous system pathology resulting in fatal encephalitis. J Virol. 2008; 82:7078-7088. [PubMed: 18480436]

120. Schonberger K, Ludwig MS, Wildner M, Weissbrich B. Epidemiology of subacute sclerosing panencephalitis (SSPE) in Germany from 2003 to 2009: a risk estimation. PLoS ONE. 2013; 8:e68909. [PubMed: 23874807]

121. Campbell H, Andrews N, Brown KE, Miller E. Review of the effect of measles vaccination on the epidemiology of SSPE. Int J Epidemiol. 2007; 36:1334-1348. [PubMed: 18037676]

122. Esiri MM, Oppenheimer DR, Brownell B, Haire M. Distribution of measles antigen and immunoglobulin-containing cells in the CNS in subacute sclerosing panencephalitis (SSPE) and atypical measles encephalitis. J Neurol Sci. 1982; 53:29-43. [PubMed: 7035621]

123. Anlar B, Soylemezoglu F, Aysun S, Kose G, Belen D, Yalaz K. Tissue inflammatory response in subacute sclerosing panencephalitis (SSPE). J Child Neurol. 2001; 16:895-900. [PubMed: 11785503]

**124. Lawrence DM, Patterson CE, Gales TL, D'Orazio JL, Vaughn MM, Rall GF. Measles virus spread between neurons requires cell contact but not CD46 expression, syncytium formation, or extracellular virus production. J Virol. 2000; 74:1908-1918. Electron microscopy was used in this study to demonstrate that neuronal spread of measles virus occurs through the synaptic cleft and is not dependent on extracellular budding and binding to the measles virus receptor. [PubMed: 10644364]

125. Liebert UG, Schneider-Schaulies S, Baczko K, ter Meulen V. Antibody-induced restriction of viral gene expression in measles encephalitis in rats. J Virol. 1990; 64:706-713. [PubMed: 2296081]

126. Bodian D. Histopathologic basis of clinical findings in poliomyelitis. Am J Med. 1949; 6:563578. [PubMed: 18119382] 
127. Shieh WJ, Jung SM, Hsueh C, Kuo TT, Mounts A, Parashar U, Yang CF, Guarner J, Ksiazek TG, Dawson J, et al. Pathologic studies of fatal cases in outbreak of hand, foot, and mouth disease, Taiwan. Emerg Infect Dis. 2001; 7:146-148. [PubMed: 11266307]

128. Leis AA, Fratkin J, Stokic DS, Harrington T, Webb RM, Slavinski SA. West Nile poliomyelitis. Lancet Infect Dis. 2003; 3:9-10. [PubMed: 12505023]

129. Gelpi E, Preusser M, Garzuly F, Holzmann H, Heinz FX, Budka H. Visualization of Central European tick-borne encephalitis infection in fatal human cases. J Neuropathol Exp Neurol. 2005; 64:506-512. [PubMed: 15977642]

130. Solomon T, Kneen R, Dung NM, Khanh VC, Thuy TT, Ha DQ, Day NP, Nisalak A, Vaughn DW, White NJ. Poliomyelitis-like illness due to Japanese encephalitis virus. Lancet. 1998; 351:1094-1097. [PubMed: 9660579]

*131. Samuel MA, Wang H, Siddharthan V, Morrey JD, Diamond MS. Axonal transport mediates West Nile virus entry into the central nervous system and induces acute flaccid paralysis. Proc Natl Acad Sci U S A. 2007; 104:17140-17145. This study revealed that WNV migrates through peripheral nerves into the CNS to induce acute limb paralysis. [PubMed: 17939996]

132. Morrey JD, Siddharthan V, Wang H, Hall JO, Skirpstunas RT, Olsen AL, Nordstrom JL, Koenig S, Johnson S, Diamond MS. West Nile virus-induced acute flaccid paralysis is prevented by monoclonal antibody treatment when administered after infection of spinal cord neurons. $\mathbf{J}$ Neurovirol. 2008; 14:152-163. [PubMed: 18444087]

133. Chopra JS, Banerjee AK, Murthy JM, Pal SR. Paralytic rabies: a clinico-pathological study. Brain. 1980; 103:789-802. [PubMed: 7437890]

134. Mitrabhakdi E, Shuangshoti S, Wannakrairot P, Lewis RA, Susuki K, Laothamatas J, Hemachudha T. Difference in neuropathogenetic mechanisms in human furious and paralytic rabies. J Neurol Sci. 2005; 238:3-10. [PubMed: 16226769]

135. Mallewa M, Vallely P, Faragher B, Banda D, Klapper P, Mukaka M, Khofi H, Pensulo P, Taylor T, Molyneux M, et al. Viral CNS infections in children from a malaria-endemic area of Malawi: a prospective cohort study. Lancet Glob Health. 2013; 1:e153-160. [PubMed: 24748325]

136. Paul S, Ricour C, Sommereyns C, Sorgeloos F, Michiels T. Type I interferon response in the central nervous system. Biochimie. 2007; 89:770-778. [PubMed: 17408841]

137. Nath A, Tyler KL. Novel approaches and challenges to treatment of central nervous system viral infections. Ann Neurol. 2013; 74:412-422. [PubMed: 23913580] 


\section{HIGHLIGHTS}

- A diverse spectrum of viruses can enter the CNS, causing acute and chronic neurological disorders

- Virus-induced CNS diseases are influenced by routes of viral entry, viral tropism, and immune responses

- CNS immune reactions limit the spread of virus, but can also cause severe pathology

- Viruses can directly injure or disable cells of the CNS resulting in disease

- New animal models and therapeutic interventions are required to lessen the burden of CNS viral infections worldwide 


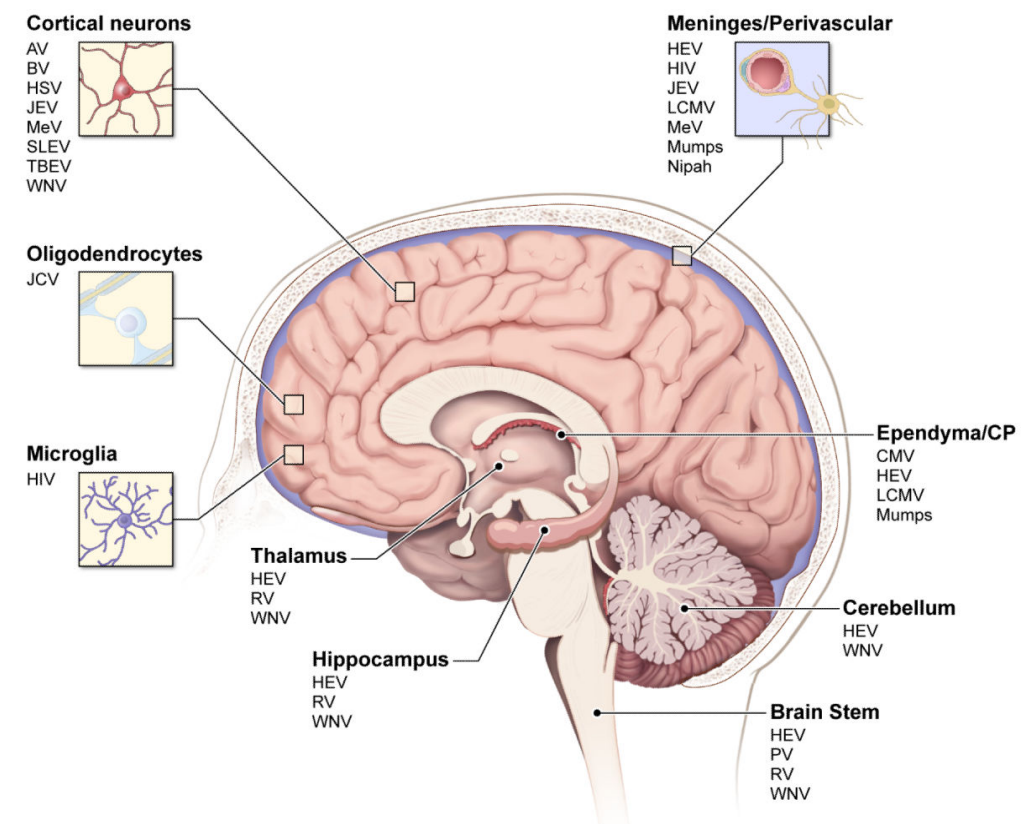

Figure 1. Immunopathogenesis of fatal meningitis induced by LCMV

A) On day 5 post-infection, small numbers of antiviral $\mathrm{CD}^{+} \mathrm{T}$ cells begin to infiltrate the subarachnoid space and engage virus-infected targets such as meningeal stromal cells, leading to chemokine release. There is little pathology in the meninges and brain parenchyma at this time point, although reactive microglia can be observed. B) On day 6 post-infection, large numbers of $\mathrm{CD}^{+} \mathrm{T}$ cells migrate into the subarachnoid space, which amplifies chemokine release and gives rise to massive, synchronized extravasation by innate myelomonocytic cells. This results in disruption of vascular tight junctions, breakdown of the glial limitans, cellular pathology, edema, and ultimately death. 


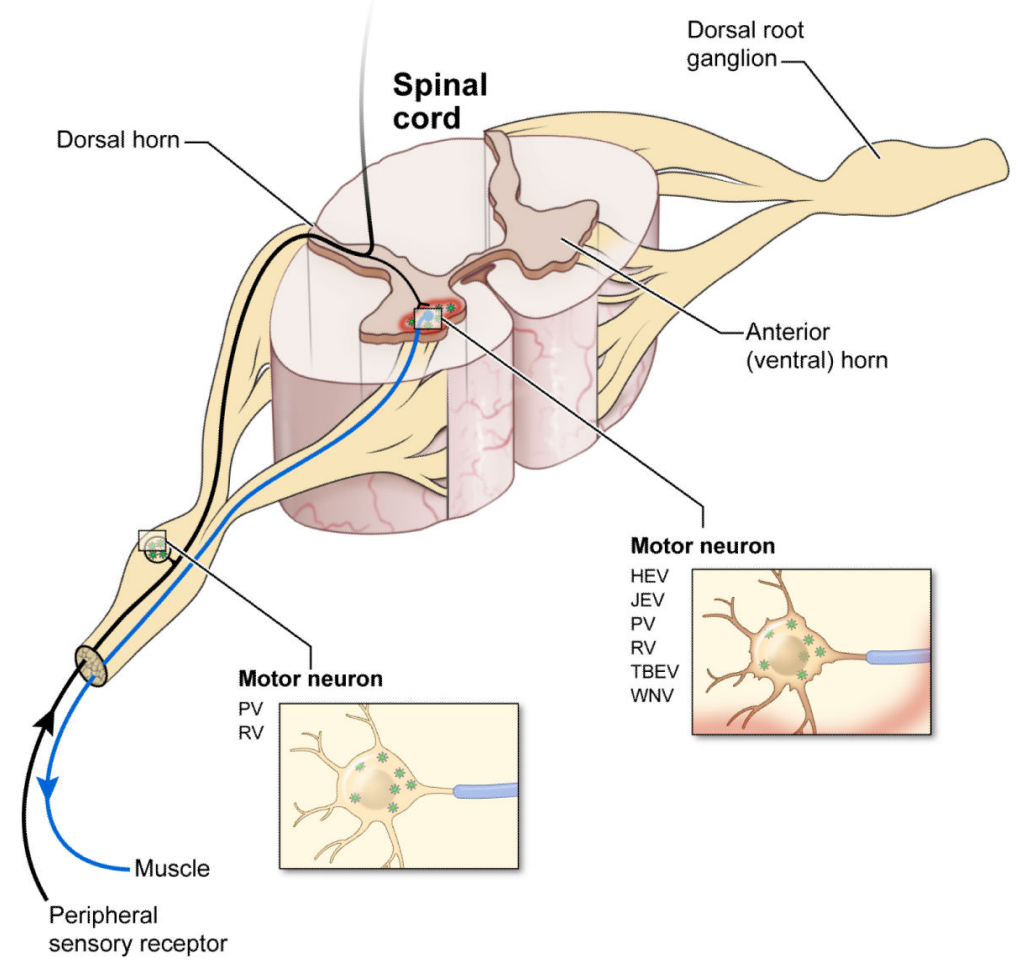

Figure 2. Brain regions affected by viruses that cause meningitis and encephalitis

Abbreviations: AV, alphaviruses, BV, bunyaviruses, CMV, cytomegalovirus, HEV, human enteroviruses, HIV, human immunodeficiency virus, HSV, herpes simplex virus, JCV, John Cunningham virus, JEV, Japanese encephalitis virus, LCMV, lymphocytic choriomeningitis virus, MeV, measles virus, Mumps, Mumps virus, Nipah, Nipah virus, PV, poliovirus, RV, rabies virus, SLEV, St. Louis encephalitis virus, TBEV, tick-borne encephalitis virus, WNV, west nile virus. 


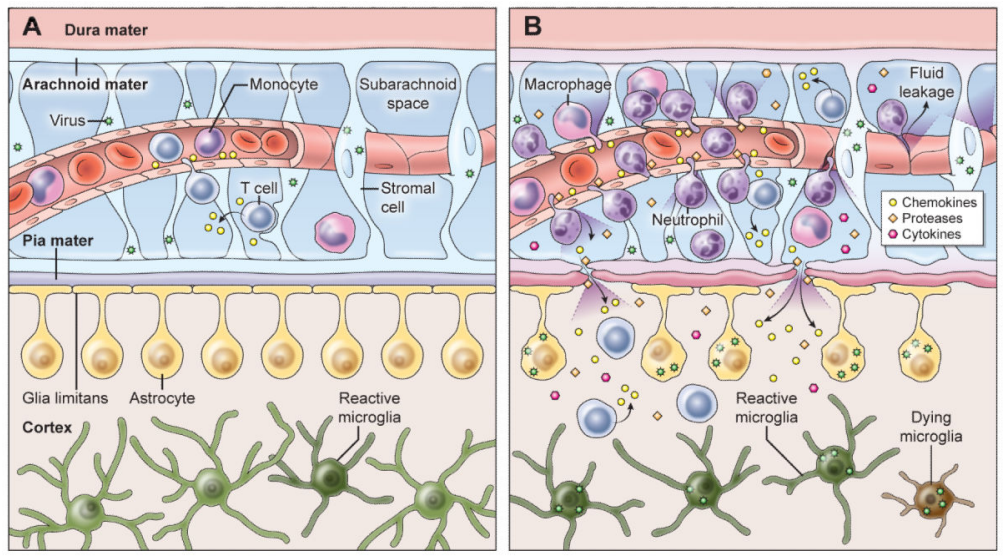

Figure 3. Spinal cord regions affected by viruses that cause myelitis

Abbreviations: HEV, human enteroviruses, JEV, Japanese encephalitis virus, PV, poliovirus, $\mathrm{RV}$, rabies virus, TBEV, tick-borne encephalitis virus, WNV, West Nile virus. 